\title{
Indonesian Clinical Practice Guidelines for Diabetes in Pregnancy
}

\author{
Dyah Purnamasari, ${ }^{1}$ Sarwono Waspadji, ${ }^{1}$ John MF Adam, ${ }^{2}$ Ahmad Rudijanto, ${ }^{3}$ Dicky Tahapary ${ }^{1}$ \\ on behalf of the Indonesian Society of Endocrinology (ISE) \\ ${ }^{1}$ Division of Endocinology and Metabolism, Department of Internal Medicine, Faculty of Medicine, University of Indonesia, \\ Cipto Mangunkusumo Hospital, Jakarta, Indonesia \\ ${ }^{2}$ Department of Internal Medicine, Jaury Jusuf Putera Hospital, Makasar, Indonesia \\ ${ }^{3}$ Department of Internal Medicine, Faculty of Medicine, Brawijaya University, Malang, Indonesia
}

\begin{abstract}
Diabetes Mellitus (DM) in pregnancy has serious impact on both mother and baby if not optimally managed. The Indonesian Task Force on Reproductive Diseases determined that diabetes in pregnancy represents a priority area in need of updated evidence-based practice guidelines. The aim of the guidelines is to provide the best evidence-based recommendations for diagnostic evaluation and management of diabetes in pregnancy. The following article summarizes the guidelines.
\end{abstract}

Keywords: diabetes, pregnancy, clinical practice guidelines, Indonesia

\section{INTRODUCTION}

In Indonesia, the prevalence of GDM (according to O'Sullivan's diagnostic criteria) was 1.9 to $3.6 \%$. In a cohort study, as many as $40-60 \%$ of this group will progress to type 2 diabetes (T2DM) or impaired glucose tolerance (IGT). In one prospective study in Makassar among 46 women with GDM, the incidence of T2DM and impaired glucose tolerance (IGT) after 6 years of delivery were $56.6 \%{ }^{1}$ Considering the serious morbidity and mortality for both mother and baby, there should be an effective screening method for pregnant women who were not previously known to have DM.

The Indonesian Clinical Practice Guidelines for Diabetes in Pregnancy is a project of the Indonesian Task Force on Reproductive Diseases, which is a collaboration of Indonesian endocrinologists caring for pregnant women with diabetes. The objective of this project is to develop clinical practice guidelines on the screening, diagnosis and management of diabetes in pregnancy which reflect the current best evidence on optimal medical practice and incorporate local data into the recommendations. It is not the intention of these guidelines to replace clinical judgment and individual decision making. Each recommendation should be evaluated in light of these elements in order to delivering optimal patient care.

\section{Summary of the Methods for Guidelines Development}

The guidelines were developed by the Indonesian Task Force on Reproductive Diseases. The Task Force reviewed

\section{ISSN 0857-1074}

Printed in the Philippines

Copyright (C) 2013 by the JAFES

Received April 25, 2013. Accepted May 17, 2013. available literatures on diabetes in pregnancy. The Task Force was able to obtain valuable feedback and suggestions to include additional evidence from the literature and to consider alternative interpretation of data. The participants contributed to and influenced the form of the final guidelines, making it a comprehensive report from various geographical origins and medical disciplines.

\section{Summary of Recommendations}

\section{Definitions}

In general, diabetes in pregnancy can be divided into two groups: 1) DM who had been previously known and subsequently became pregnant (Pregestational Diabetes Mellitus) and 2) Newly identified diabetes during pregnancy (Gestational Diabetes Mellitus/GDM). ${ }^{2}$

\section{Epidemiology}

GDM prevalence varies in each region depending to the diagnostic and examination standards used, but in general it is reported that GDM occurs in 3-5\% of normal pregnancies. $^{3}$ Ethnicity was an independent factor affecting the incidence of GDM. Although Asian women's Body Mass Index (BMI) is lower in general, they are more susceptible to GDM than their Caucasian counterparts. ${ }^{4}$

\section{Clinical signs and symptoms}

The signs and symptoms of diabetes in pregnancy are not specific. 5,6

Corresponding author: Dyah Purnamasari, MD

Division of Endocrinology and Metabolism, Department of Internal Medicine,

Faculty of Medicine University of Indonesia, Cipto Mangunkusumo National

Hospital, Jalan Salemba 6, Central Jakarta, DKI Jakarta, Indonesia

Tel. No.: $.+62213100075,+62213907703$

Fax No.: $+62213928658,+62213928659$

E-mail:dyah_p_irawan@yahoo.com 


\section{Screening and diagnosis of diabetes in pregnancy}

\section{Pregestational diabetes}

For pregnant women who have been diagnosed with diabetes before pregnancy, it is not necessary to do screening tests. ${ }^{6}$

\section{Gestational diabetes}

The Indonesian Society of Endocrinology (PERKENI) suggests to do screening tests in all pregnant women at baseline and reevaluate at 26-28 weeks of gestation if the first evaluation is normal. If the screening is only performed among high risk groups, then around 31\% of pregnant women with GDM would have been missed. ${ }^{1,2}$

PERKENI uses the WHO OGTT method (oral glucose tolerance test using $75 \mathrm{~g}$ of anhydrous glucose) for measuring fasting plasma glucose and subsequent blood glucose concentration 2 hours after glucose administration, to establish dysglycemia (DM and IGT). The implementation of the OGTT is not different from the OGTT for the general population (as stated in PERKENIDM Consensus 2011), as follows: ${ }^{7}$

- Three days before the examination, no change in diet (with enough carbohydrates) and and in their usual normal physical activities.

- Fasting for at least eight hours (starting at night) before the test, plain water is still allowed

- Sampling for fasting blood glucose concentration

- $\quad$ Drink 75 grams of anhydrous glucose in $250 \mathrm{~mL}$ water within 5 minutes.

- $\quad$ Fasting for the next two hours

- Examine blood glucose concentration two hours after glucose load

- During the examination, subject should remain seated and not allowed to smoke

The results of Oral Glucose Tolerance Test is divided into three: ${ }^{7}$

- 2 hour blood glucose $<140 \mathrm{mg} / \mathrm{dL} \rightarrow$ normal

- 2 hour blood glucose 140-199 mg/dL $\rightarrow$ impaired

- $\quad 2$ hour blood glucose $\geq 200 \mathrm{mg} / \mathrm{dL} \rightarrow \mathrm{DM}$ glucose tolerance

Particularly for pregnant women, impaired glucose tolerance group should be managed as DM.

Waspadji conducted a study to determine mean blood glucose concentrations in normal pregnancy. Normal maternal glycoHb concentration does not change significantly over gestational age, although there is a tendency for it to decrease with gestational age (Waspadji et al.) Mean concentration of fasting glucose among normal pregnant women is significantly lower, while mean concentration of 2-hour post meal glucose is significantly higher during the 3rd trimester of pregnancy, in comparison to non-pregnant women. ${ }^{8}$
Based on that study, the blood glucose target in pregnancy should be lower that that of non-pregnant women.

\begin{tabular}{lcc}
$\begin{array}{l}\text { Table 1. Mean blood glucose concentrations of normal } \\
\text { pregnant women }\end{array}$ & $\begin{array}{c}\text { Fon } \\
\text { Fasting Blood Glucose } \\
(\mathbf{m g} / \mathbf{d L})\end{array}$ & $\begin{array}{c}\text { 2 hours post prandial } \\
(\mathbf{m g} / \mathbf{d L})\end{array}$ \\
\hline Not Pregnant & $83,87 \pm 7,15$ & $98,71 \pm 9,03$ \\
& & \\
Pregnancy & & $90,00 \pm 8,80$ \\
trimester 1 & $75,47 \pm 8,46$ & $93,75 \pm 10,08$ \\
trimester 2 & $71,91 \pm 7,01$ & $100,45 \pm 7,84$ \\
trimester 3 & $70,00 \pm 8,93$ &
\end{tabular}

\section{Ultrasonography (USG)}

USG should be perfomed in order to determine the growth of the fetus. Based on USG result, the obstretician and endocrinologist can evaluate the treatment impact to the mother and baby and after that, they can adjust the next treatment plan, particularly the blood glucose target. ${ }^{9}$

\section{Management}

Management of diabetes in pregnancy should be implemented as an integrated approach by a specialist in internal medicine, obstetrics gynecology, nutritionists and pediatricians. The purpose of management is to reduce both maternal and perinatal morbidity and mortality. The management of diabetes in pregnancy include meal planning and physical activity, education and insulin therapy if the meal planning can not achieve the targetted blood glucose control. ${ }^{1,2,3}$

\section{Pregestational diabetes}

Among pregestational diabetes, there is no recommendation for continuing the oral hypoglycemic agent. In pregnant women with T2DM previously controlled with diet, blood glucose monitoring is necessary to detect if diet planning is no longer adequate to control blood glucose, thereafter insulin therapy is needed. While in pregnant women with T2DM controlled with oral hypoglycemic drugs, the treatment regimen should be changed from oral hypoglygemic drugs to insulin. Those who already receive insulin therapy will require insulin dose adjustment, especially after the second trimester onwards considering increasing incidence of insulin resistance in the period. ${ }^{4}$

\section{Gestational diabetes}

In general, the management of GDM is similar to the management of DM, except for the use of oral hypoglycemic drugs. Until now, the use of oral hypoglycemic drugs in gestational diabetes is not recommended. ${ }^{1,5,6,10,11}$ Some experts do not absolutely prohibit the use of oral hypoglycemic drugs on GDM for remote areas with less facilities and no insulin available. ${ }^{6,12}$ 


\section{Target control of diabetes in pregnancy}

Target glycemic control in pregnant women with diabetes are in accordance with Gestational Diabetes Mellitus Consensus from PERKENI, which are: ${ }^{1}$

$$
\begin{array}{lll}
\text { - } & \text { Fasting blood glucose } & : 95 \mathrm{mg} / \mathrm{dL} \\
\text { - } & \text { 2 hours post prandial blood glucose } & : 120 \mathrm{mg} / \mathrm{dL}
\end{array}
$$

The use of $\mathrm{HbA} 1 \mathrm{c}$ for monitoring and control targets is not recommended given the weakness of the relationship between $\mathrm{HbA} 1 \mathrm{c}$ with risk of macrosomia incidence and negative impact on other pregnancy., ${ }^{5,6}$ However, examination of $\mathrm{HbA} 1 \mathrm{c}$ during the first trimester of pregnancy may predict the IGT and DM in the next two trimesters. ${ }^{13}$

Incidence of macrosomia can be prevented by performing ultrasonography (USG) periodically to assess the fetal abdominal circumference. The combination of maternal glycemic control and the results of an ultrasound examination can guide clinicians in monitoring and determining the mother's blood glucose targets. For example, if the results of the fetal abdominal circumference is in the normal range then it is not necessary to do strict monitoring. Conversely, if the fetal abdominal circumference is beyond the normal limit then the glucose target should be lower. ${ }^{6,9}$

\section{a. Medical Nutrition Therapy and Physical Activity}

The goal is to achieve normoglycemia and ensure the growth and optimal fetal development. ${ }^{1}$ In normal pregnancy, the expected weight gain during pregnancy varies, which is influenced by pre-pregnancy weight. The Institute of Medicine recommends weight gain of around 7 $\mathrm{kg}$ in obese women (BMI $\geq 30 \mathrm{~kg} / \mathrm{m} 2$ ) and weight gain of up to $18 \mathrm{~kg}$ in women who were underweight (BMI $<18.5$ $\mathrm{kg} / \mathrm{m} 2$ ) before pregnancy. The weight gain recommendations during pregnancy based on prepregnancy BMI are:3,14

\begin{tabular}{cclc}
\hline No. & BMI $\left(\mathbf{k g} / \mathbf{m}^{2}\right)$ & \multicolumn{1}{c}{ Weight Gain } & Weight Gain Rates \\
\hline 1. & $<18.5$ & $\begin{array}{l}28-40 \text { pounds } \\
(12.5-18 \mathrm{~kg})\end{array}$ & $1-1.3$ pounds/week \\
2. & $18.5-24.9$ & $\begin{array}{l}25-35 \text { pounds } \\
(11.5-16 \mathrm{~kg})\end{array}$ & $0.8-1$ pounds/week \\
3. & $25-29.9$ & $\begin{array}{l}15-25 \mathrm{pound} \\
(7-11.5 \mathrm{~kg})\end{array}$ & $0.5-0.7$ pounds/week \\
& & $\begin{array}{l}15 \text { pounds } \\
(6.8 \mathrm{~kg})\end{array}$ & $0.4-0.6$ pounds/week \\
4. & $>30$ &
\end{tabular}

A study by Mangunkusumo on 26 women with GDM reported that in all of the women, blood glucose concentration can be controlled with meal planning. This shows the role of meal planning is very important in the control of blood glucose. ${ }^{15}$

Pregnant women with GDM should receive nutritional counseling. In general, the calculation of caloric requirements for pregnant women with diabetes were as follows: ${ }^{16,17}$

- $\quad 35-40 \mathrm{kcal} / \mathrm{kg}$ desirable body weight for underweight

- $30-34 \mathrm{kcal} / \mathrm{kg}$ for normal weight

- $\quad 23-25 \mathrm{kcal} / \mathrm{kg}$ for overweight subjects

For obese women $(\mathrm{BMI}>30 \mathrm{~kg} / \mathrm{m} 2)$, a $30-33 \%$ calorie restriction (to $25 \mathrm{kcal} / \mathrm{kg}$ actual weight per day) has been shown to reduce hyperglycemia and plasma triglycerides with no increase in ketonuria.

Composition settings and allocation of meal portion has no difference with non-pregnant diabetic, with protein intake $1-1,5 \mathrm{gram} / \mathrm{kg} \mathrm{BW.}{ }^{1}$

It is recommended that all women with GDM do physical activity for 30 minutes a day. Walking and arm exercise when seated for 10 minutes after each meal will be quite helpful. The American Diabetes Association recommends starting or continuing a program of moderate exercise without medical or obstetrical contraindications (vaginal bleeding, faintness, decreased fetal activity, generalized edema, low back paint). Recommended forms of exercise include walking, stationary bicycling, low-impact aerobics, and swimming 1,18

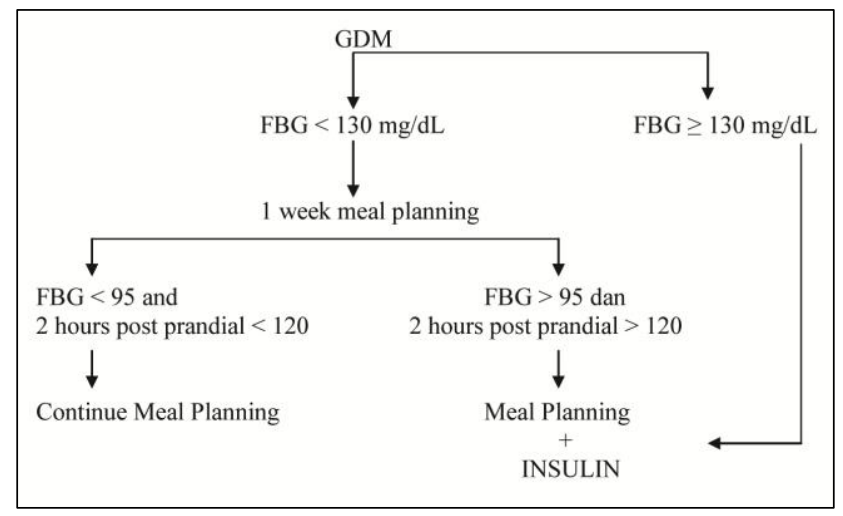

Quoted from GDM Perkeni Consensus

Figure 1. Algorithm of Therapy in GDM

\section{b. Oral Hypoglycemic Drug Therapy}

Studies that previously have been done still have pros and cons to the use of oral hypoglycemic drugs in pregnancy. So far, glibenclamide and metformin have been studied several times for their use in pregnancy. Consideration of the use of oral hypoglycemic drugs is whether the drug passes through the placental barrier and if so, whether it will cause adverse effect on the fetus. ${ }^{19-23}$

A study from the Department of Obstetrics and Gynecology, Faculty of Medicine, University of Indonesia, reported the effects of metformin compared to diet in pregnant women with gestational age 24-30 weeks diagnosed with GDM. GDM characteristics of the study 
are likely older age ( $>31$ years), multiparous, obese, have a close family history of DM, has a history of GDM and history of previous macrosomic baby. The use of metformin compared with standard therapy, dietary planning in first 2 weeks, has no significant difference in controlling blood glucose in the 2nd, 4 th and 6th weeks. The most common fetal complication is hypoglycemia $(31.7 \%)$ in addition to macrosomia $(26.8 \%)$ and large for gestational age. ${ }^{24}$

So far there has been no recommendation on the use of metformin and glibenclamide in pregnancy. The evidence is limited and we still need further research and monitoring to detect possible long-term side effects in babies.

\section{c. Insulin Therapy}

So far, human insulins are the safest insulin among pregnant women with diabetes who cannot achieve blood glucose control by meal planning. The use of insulin analogues is still controversial and no study had recommended the use of insulin analogues in pregnancy. Consideration for not recommending insulin analogues in pregnancy includes its amino acid structure that is different from human insulin. The difference in the structure of this amino acid resulted in a difference of affinity between insulin analogues and human insulin to the insulin receptor and IGF-1 receptors. Given the concept that HPL (whose concentration peaks in the third trimester of pregnancy) is through IGF-1 receptor, the strong affinity between insulin analogues and IGF-1 receptor is feared to disrupt the hormones and outcome of pregnancy. ${ }^{25}$

According to GDM consensus, characteristics and fasting blood glucose 2 hours post prandial can be a guide in the selection of insulin regimen, which can be seen in Table 5 below: ${ }^{1}$

\begin{tabular}{|c|c|c|c|c|}
\hline \multirow[b]{2}{*}{$\begin{array}{l}\text { Blood } \\
\text { Glucose } \\
\text { Pattern }\end{array}$} & \multicolumn{4}{|c|}{ Schedule Delivery of Insulin } \\
\hline & $\begin{array}{c}07.00 \\
\text { Before } \\
\text { Breakfast }\end{array}$ & $\begin{array}{l}13.00 \\
\text { Before } \\
\text { Lunch }\end{array}$ & $\begin{array}{c}19.00 \\
\text { Before } \\
\text { Dinner }\end{array}$ & $\begin{array}{l}22.00 \\
\text { Before } \\
\text { Sleep }\end{array}$ \\
\hline \multirow{3}{*}{$\begin{array}{c}\text { n High } \\
\text { pp Normal } \\
\text { n High } \\
\text { pp High }\end{array}$} & - & - & - & $\mathrm{M}$ \\
\hline & \multicolumn{4}{|c|}{ Or } \\
\hline & C & C & C & M \\
\hline
\end{tabular}

\section{Monitoring in women with gestational diabetes after delivery}

After delivery monitoring covers all aspects related to the risk of incident diabetes and other metabolic abnormalities associated with insulin resistance. During this period, the physician should consider several factors: 1) impaired glucose metabolism and risk of cardiovascular disease
(CVD), 2) the process of breastfeeding, 3) appropriate use of contraception, and 4) type 2 diabetes prevention. ${ }^{6}$

Examination of blood glucose should be routinely performed before women leave the hospital as early monitoring. Examination of fasting blood glucose $\geq 126 \mathrm{mg}$ /dL or blood glucose 2 hours post prandial $\geq 200 \mathrm{mg} / \mathrm{dL}$ confirm the diagnosis of DM. If the result is normal, subsequent monitoring can be done at control (approximately 6-12 weeks post-partum or postparturition) by performing an oral glucose tolerance test. Considering that the physiological conditions of insulin resistance is expected to have fully recovered one year after giving birth, then this period is also recommended for monitoring. If the results remain normal, subsequent monitoring can be carried out every three years by doing OGTT. In the high risk group, monitoring can be done more frequently. 6,10

GDM women who have given birth are still advised to undergo dietary planning with or without drugs to maintain optimal glycemic control and adequate nutrition status in order to continue breastfeeding their babies. Human insulin, glibenclamide and glipizide are safe for breastfeeding. Studies of metformin use in lactating women is limited. Metformin is also excreted via human breast milk, but did not result in a negative impact on the baby. However, they require large studies to prove the safety of metformin in breastfeeding women. ${ }^{6}$

\section{Prognosis}

Diabetes in pregnancy which is not optimally managed will cause morbidity in mothers and babies. Short term effects on the fetus are risk of macrosomia, congenital anomalies or low birth weight. $1,5,6,10,11,32$ Incidence of macrosomia in GDM with poor glycemic control was $40 \%$. Macrosomia increases the risk of dystocia during labor and asphyxia. Increased risk of macrosomia is associated with blood glucose concentrations after meal instead of the average blood glucose concentration in a single day. Long term effects on the mother include the risk of developing impaired glucose tolerance and type 2 diabetes. While the baby may have an increased risk of later obesity and IGT. Therefore, adequate glycemic control during pregnancy is important to prevent complications in the mother and baby. $5,6,11$

\section{Authors' Disclosure}

This review was written independently; no company or institution supported it financially. Authors declared no inherent conflicts of interest.

\section{References}

1. Konsensus Diagnosis dan Penatalaksanaan Diabetes Melitus Gestasional. Perkumpulan Endokrinologi Indonesia, 1997.

2. Waspadji S. Diabetes mellitus pada kehamilan. Dalam: Markum, HMS. Sudoyo AW, Effendy S, Setiati S, Gani RA, Alwi I. Naskah lengkap Pertemuan Ilmiah Tahunan Ilmu Penyakit Dalam 1997. Bagian Ilmu Penyakit Dalam FKUI/ RSUPN dr. Cipto Mangunkusumo, Jakarta, 1997. 
3. Ben-Haroush A, Yogev Y, Hod M. Epidemiology of gestational diabetes melitus and its association with type 2 diabetes. Diabet Med. 2004; 21:103-13.

4. Retnakaran R, Hanley AJG, Connely PW, Sermer M, Zinman B. Ethnicity modifies the effect of obesity on insulin resistance in pregnancy: A comparison of Asian, South Asian and Caucasian women. J Clin Endocrinol Metab. 2006; 91: 93-7.

5. Hod M, Yogey Y. Goals of metabolic management of gestational diabetes. Diabetes Care. 2007; 30(suppl2): S180-7.

6. Metzger BE, Buchanan TA, Organizing Committee. Summary and recommendations of the Fifth International Workshop-Conference on Gestational Diabetes Mellitus. Diabetes Care. 2007; 30(suppl2): 251S$60 \mathrm{~S}$.

7. Konsensus diagnosis dan penatalaksanaan diabetes melitus di Indonesia. Perkumpulan Endokrinologi Indonesia, Jakarta 2006.

8. Waspadji S, Napitupulu B, Hasanuddin F, Supartondo. Kadar glukosa darah puasa, sesudah makan dan kadar gliko $\mathrm{Hb}$ pada wanita hamil non diabetes melitus. Dalam: Tjokroprawiro A, Sukahatya M, Suhadi B, Sutjahjo A, Tandra H, Buku naskah lengkap. Kongres nasional II Perkumpulan Endokrinologi Indonesia. Surabaya 1989.

9. Kjos SL, Schaefer-Graf UM, Modified therapy for gestational diabetes using high risk and low risk fetal abdominal circumference growth to select strict versus relaxed maternal glycemic target. Diabetes Care. 2007; 30 (suppl 2): S200-5.

10. Kjos SL, Buchanan TA. Gestational Diabetes Mellitus. N Engl J Med. 1999; 341: 1749-56.

11. Ben-Haroush A, Yogev Y, Hod M. Epidemiology of gestational diabetes melitus and its association with type 2 diabetes. Diabet Med. $2004 ; 21: 103-13$

12. Jovanovic L. Point: Oral hypoglycaemic agents should not be used to treat diabetic pregnant women. Editorials. Diabetes Care. 2007; 30: 2976-9.

13. Committee on Nutritional Status During Pregnancy and Lactation, Institute of Medicine. Nutrition During Pregnancy: Part I: Weight Gain, Part II: Nutrient Supplements. National Academy Press, Washington, DC, 1990.

14. Bloomgarden ZT. Gestational Diabetes Mellitus and Obesity. Diabetes Care. 2010; 33(5). E60-e65.

15. Chamim. Penatalaksanaan diabetes dalam kehamilan. Tesis. Bagian Obstetri \& Ginekologi FKUI/ RSCM Jakarta 1995.

16. Reader DM. Medical nutrition therapy and lifestyle interventions. Diabetes Care. 2007; 30: S188-S193.

17. Snyder J, Gray-Donald K. Koski KG. Predictors of infant birthweight in gestational diabetes. Am J Clin Nutr. 1994; 59 : 1409-1414.

18. Harris GD, White RS. Diabetes management and exercise in pregnant patients with diabetes. Clinical Diabetes. 2005; 23(4) :165-8.

19. Balaji V, Madhuri BS, Ashalatha S, Sheela S, Suresh S, Seshiah V. A1c in gestational diabetes melitus in Asian Indian women. Diabetes Care. 2007; 30: 1865-7.
20. Kahn BF, Davies JK, Lynch AM, Reynolds RM, Barbour LA Predictors of glyburide failure in the treatment of gestational diabetes. Obstet Gynecol. 2006; 107: 1303-9.

21. Langer O, Conway DL, Berkus MD, Xenakis EM, Gonzales O. A comparison of glyburide and insulin in women with gestational diabetes melitus. N Engl J Med. 2000; 343: 1134-8.

22. Moore TR. Glyburide for the treatment of gestational diabetes. A critical appraisal. Diabetes Care. 2007; 30 (suppl2): s209-13.

23. Ho FL, Liew $\mathrm{CH}$, Cunanan EC, Lee KO, Oral hypoglycaemic agents for diabetes in pregnancy. An appraisal of the current evidence for oral anti-diabetic drug use in pregnancy. Ann Acad Med Singapore. 2007; 36; 672-8.

24. Rowan JA, Hague WM, Gao W, Battin MR, Moore P. Metformin versus insulin for the treatment of gestational diabetes. N Engl J Med. 2008; 358:2003-15.

25. Wendyansyah. Perbandingan pengendalian gula darah dan luaran kehamilan pasien diabetes mellitus gestasional pada pemberian metformin dengan metode standar. Tesis. Program Studi Obstetri dan Ginekologi Program Pendidikan Dokter Spesialis I. FKUI RSCM Jakarta 2005

26. Jovanovic L, Pettitt DJ. Treatment with insulin and its analogs in pregnancies complicated by diabetes. Diabetes Care. 2007; 30(suppl2) S220-4.

27. Pantalone KM, Faiman C, Olansky L. Insulin glargine use during pregnancy. Endocrine Practice. 2011;17 (No.3).

28. deValk HW, Visser GHA. Insulin during pregnancy, labour, and delivery. Best Practice \& Research Clinical Obstetrics and Gynaecology. 2011; 25 :65-76.

29. Negrato CA, Rafacho A, Negrato G, Teixeira MF, Araujo CAR, et al Glargine vs NPH insulin therapy in pregnancies complicated by diabetes: An observational cohort study. Diabetes Research and Clinical Practice. 2010; 89: 46-51.

30. Leperq J, Lin J, Hall GC, Wang E, Dai MP, et al. Meta-Analysis of maternal and neonatal outcomes associated with the use of insulin glargine versus NPH insulin during pregnancy. Obstetrics and Gynecology International. doi:10.1155/2012/649070.

31. Cianni GD, Volpe L, Ghio A, Lencioni C, Cuccuru I, Benzi L, et al. Maternal metabolic control and perinatal outcome in women with gestational diabetes melitus treated with lispro or aspart insulin Comparison with regular insulin. Letters. Diabetes Care. 2007; 30: e11.

32. Pettitt DJ, Ospina P, Howard C, Zisser H, Jovanovic L. Efficacy, safety and lack of immunogenicity of insulin aspart compared with regular human insulin for women with gestational diabetes mellitus. Diabet Med. 2007; 24: 1129-35.

33. Crowther CA, Hiller JE, Moss JR, McPhee AJ, Jeffries WS, Robinson JS, et al. Effect of treatment gestational diabetes mellitus on pregnancy outcome. N Engl J Med. 2005; 352; 2477-86.

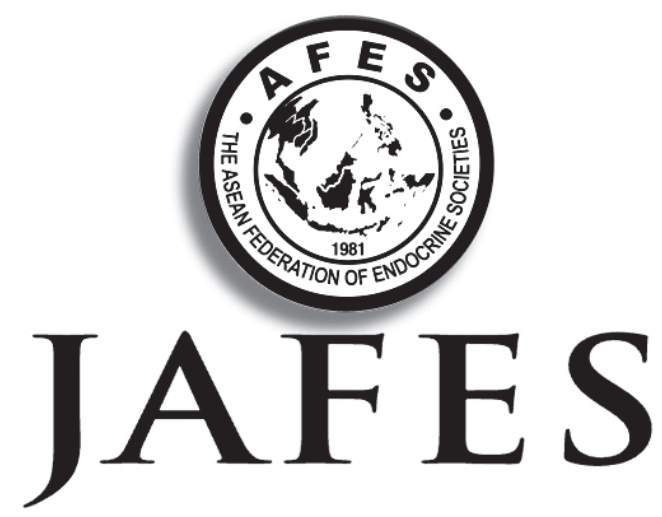

\section{A new venue for publishing your original articles. Visit www.ASEAN-endocrinejournal.org for Instructions to Authors.}

